\title{
From Idealism-Rationalism to Pragmatism- Materialism: Shift in Understanding Religion to Islamic Society in East Java, Indonesia
}

\author{
Ishomuddin \\ University of Muhammadiyah Malang \\ ummishom@gmail.com
}

\begin{abstract}
This research is conducted related to the tendency of society in understanding Islam in globalization era. With the many challenges faced in life, there is a change in understanding Islam from idealism-rationalism toward pragmatismmaterialism. From the social phenomenon mentioned above, this research focuses on the following questions: (1) How is the understanding and the interpretation of religion for modern society today?; (2) How does modern society behave in addressing new flows related to new ways of gaining material or economic benefits through financial multiplier? This research used the social definition paradigm and qualitative approach. This research was conducted in several cities in East Java, Indonesia. The results showed that the three groups of economic class (high, middle, and lower) who actively practice religion and experience changes in attitudes toward religion are adhered to the material and economic needs in the family.

Keywords: Idealism-rationalism, Pragmatismmaterialism, Understanding religion, Islamic societ
\end{abstract}

\section{INTRODUCTION}

The study of the relationship between religion and the behavior of its adherents is still very interesting. The relationship between religion and its adherents focuses on the economic, political, social, and cultural fields. In the field of economics, it recently emerges various unique religious schools and receives a response from some modern society. The phenomenon of modern society's behavior and its relation to religious beliefs in economic issues has become a focus on this research-based article. Many problems of life caused by the economic problems and faced by the lower and middle class society generate new streams that offer the ease of getting luck or doubling the money. The emergence of new Islamic streams that offer easy ways to solve economic or financial problems is offered everywhere. Communities no longer use rational ways to meet the material or economic demands of the family, but they resort to ways that are sometimes seen as irrational.

From the social phenomenon mentioned above, this research focuses on the following questions: how is the understanding and interpretation of religion for modern society today, and how the behavior of modern society in addressing the new flow associated with new ways to gain material or economic benefits through financial multiplying.

\section{LITERATURE REVIEW}

Religion is a universal feature of social human life in the sense that all societies have qualified ways of thinking and behavior patterns called "religion". [5] Mostly, religious-themed includes the superstructure. Religion consists of symbols, images, beliefs, and specific values by which human beings interpret their existence. Because religion also contains elements of ritual, it is classified in the social structure.

Bellah describes the highest degree to which the mythical world is associated with the detailed features of the actual world. Not only every clan and local group are formulated related to ancient figures and settlement events of yore, but also every mountain, rock, and tree is explained in connection with mythical creatures. But these spiritual beings are not gods because they do not rule the world and are not worshiped. [1]

Bellah's evolutionary scheme has benefits, and the scheme is instructive in some kind of general way. His emphasis is on the objectification of power or supernatural beings in the early stages of religious evolution, as well as its emphasis on the evolution of the world-refusal theme with the emergence of historical religions, is an important outlook. But its tendency is to see all primitive religions.

A single type can change the understanding of religious life in primitive societies. This problem is resolved in the classification of Wallace's evolutionary religious systems. Wallace sees the religion of a society as a cult of praise. A cult of worship is a set of rituals all of which have the same general purposes, all 
are explicitly rationalized by a similar or related set of beliefs, and supported by the same social group. [12]

Wallace has his conception of monotheistic religion in the religions of the historical world that arose during or after the first thousand years BC. But as Guy Swanson [6] puts it, there are a number of primitive and ancient societies who worship God whom is believed to be the sole creator of this world. Swanson identifies this form of religious practice as the worship of the "high gods", and through a study of 50 primitive and ancient societies he attempted to specify the social conditions in which the belief in the supreme deity emerged.

Table 1: Religion in Social-Cultural Evolution

\begin{tabular}{|c|c|c|}
\hline Retigion Dppe (Watlace Scheme) & $\begin{array}{l}\text { : Technotogy Level } \\
\text { special society }\end{array}$ & : Example \\
\hline $\begin{array}{l}\text { Shamanik: there is only the order } \\
\text { individual worship and Shamanic }\end{array}$ & : Hunters & $\begin{array}{l}\text { : Eskimo, Kung, Mbuti from } \\
\text { Central Africa }\end{array}$ \\
\hline $\begin{array}{l}\text { Communal: : there is } \\
\text { order individual worship, shamanic } \\
\text { and comunal }\end{array}$ & :A simple horticulture & $\begin{array}{l}\text { : Tobrian community Island and } \\
\text { many North American Indian } \\
\text { tribes and Communal }\end{array}$ \\
\hline $\begin{array}{l}\text { Olympian: there are institutions of } \\
\text { individual worship, shamanic, } \\
\text { communal, and political } \\
\text { ecclesiastics }\end{array}$ & $\begin{array}{l}\text { : Intensive horticulture, and } \\
\text { ancient farms }\end{array}$ & $\begin{array}{l}\text { : Maya, Aztec, Inca, Greece, and } \\
\text { ancient Roman, and Africa } \\
\text { kingdoms }\end{array}$ \\
\hline $\begin{array}{l}\text { Monotheistic : There is } \\
\text { Individualistic worship, shamanic, } \\
\text { communal, and pacing } \\
\text { monotheistic }\end{array}$ & $\begin{array}{l}\text { : A complex agrarian order } \\
\text { and contemporary } \\
\text { industry }\end{array}$ & $\begin{array}{l}\text { : China and ancient India, centuries } \\
\text { of Europe, westem capitalism, } \\
\text { and eclectic contemporary } \\
\text { Japanese }\end{array}$ \\
\hline
\end{tabular}

One of the findings of Swanson's research is that the belief in the supreme god is strongly related to the presence of a number of powerful groups in a hierarchically structured society. Guy Swanson also produces other findings that are directly related to an understanding of religious evolution. The results of Swanson's study show that supernatural sanctions against moral behavior are most likely to exist in societies that have the strongest factor associated with supernatural sanctions against morality as the existence of social classes. Another study concerning religious evolution is from Ralp Underhill. Like Swanson, Underhill sought to determine the specific social conditions responsible for a belief in a supreme deity in society. Furthermore, Underhill insists that while the complexities of the economy and political complexity have a strong connection with the existence of the supreme deity and the stronger economic complexity of the relationship. Underhill interprets his findings in terms of Karl Marx.[11]

Karl Marx [10], Charles Glock and Rodney Staark 9] sought to analyze the relationship between religion and radical politics. One of their studies focused on the relationship between religion and political party affiliation in France. They found a very strong link between political conservatism and orthodox religious belief and practice, and the existence of a comparable antagonism between orthodox religion and radical politics. In general, they found that the more radical a party, the more it tends to be that party members deny traditional religious beliefs and practices. Then Glock and Stark also investigated the relationship between religion and politics in the Netherlands.

In Britain, there has been a very similar form of Protestantism, Anglicanism. Luther was soon followed by other Protestant reformers, and the most prominent was Huldrych Zwingli of Switzerland and the Frenchman Jean Calvin (John Calvin). Calvin is more important. Although he was French, Calvin spent most of his time in Germany and Switzerland so that the city became the birthplace of Calvinism. Calvin's ideas contain much in common with Luther's ideas and are clearly influenced by Luther. Of course, there are many different traits with his theology. Perhaps, the most important is his famous doctrine of fate, who believes that an eternal God has predestined some to salvation and that others have anathema. This doctrine is a modification of Luther's understanding of salvation through faith, and is, of course, a deviation from the Catholic church's approach to salvation. [13]

Yinger [14], using the Troeltsch [7] concept, distinguishes a number of additional types in order to capture the full meaning of religious organizations in industrial societies. According to Yinger, there are five basic types of religious groups: ecclesia, denominations, established sects, sects, and cults.

Figure 1. Denomination [8]

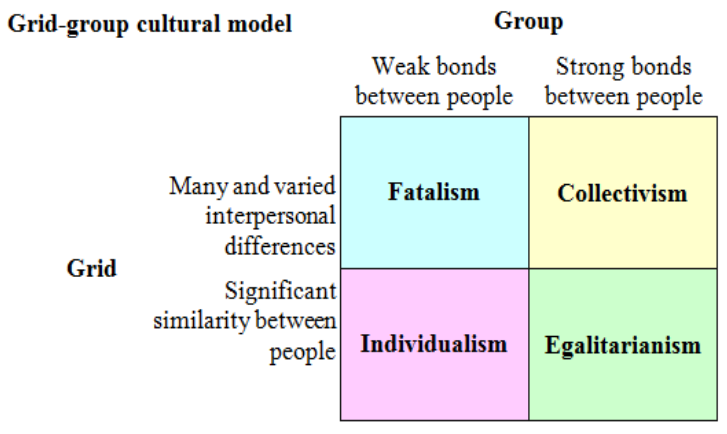

\section{METHODOLOGY}

This research uses social definition paradigm.[4] Because the paradigm used is a social definition, the approach of this research is qualitative.

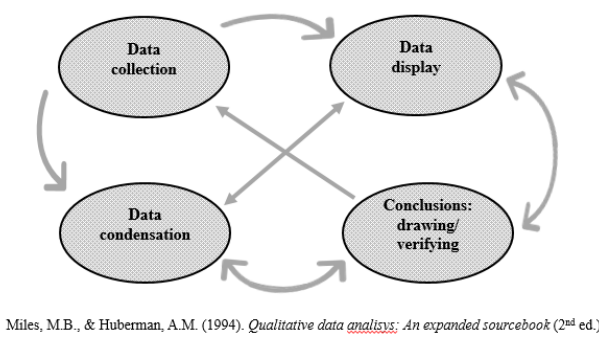


This study was conducted in several cities in East Java, where the strange Islamic sect is located. While the informants of this research are ex-former followers of a strange Islamic school founded by some strange flow figures. The total number of followers is about 200 people. However, the researcher chose informants by purpose and theoretical sampling using several categories, among others, age is 25-60 years old, economic condition of lower economic class (poor), education, graduate from elementary school up to bachelor, and Islamic experience that is traditional and modern Islam. Each category selected 5 people.

Table 1: Selected Informants

\begin{tabular}{lllll}
\hline Amount & :Age/years & $\begin{array}{c}\text { Economic } \\
\text { Condition }\end{array}$ & Education: & $\begin{array}{l}\text { Islamic } \\
\text { Experience }\end{array}$ \\
\hline 5 people & $: 25-60$ & $: \begin{array}{l}\text { Lower } \\
\text { (poor) }\end{array}$ & $\begin{array}{l}\text { Elementary- : Traditional } \\
\text { Bachelor }\end{array}$ \\
5 people & $: 25-60$ & $\begin{array}{l}\text { Middle } \\
\text { class }\end{array}$ & $\begin{array}{l}\text { Elementary- : Traditional } \\
\text { Bachelor }\end{array}$ \\
5 people & $: 25-60$ & $\begin{array}{l}\text { : High } \\
\text { class }\end{array}$ & $\begin{array}{l}\text { Elementary- } \\
\text { Bachelor }\end{array}$ \\
\hline
\end{tabular}

Data analysis uses an interactive way model introduced by Miles and Huberman [3]. Practically, the flow of analysis is as follows:

The data are analyzed using interactive model. Researcher view analysis as three concurrent flows of activity: (1) data condensation, (2) data display, and (3) drawing conclusion/verification. The interactive model explores each of these components deeply as the researcher processes through the book.

The data condensation refers to the process of selecting, focusing, simplifying, abstracting, and/or changing data that appears in the full corpus (body) of field-written notes, interview transcripts, documents, and other empirical materials.

The second major flow of the analysis activity is data view. In general, the view is a collection of compressed and uncompressed information that allow the conclusion and action. In our course of work, we get convinced that a good exhibition is the main way to a strong qualitative analysis. The screens discussed and illustrated in this article cover many types of matrices, graphs, charts, and networks. All are designed to collect organized information into an easy accessible short form so that analysts can see what's happening and draw a justified conclusion, or move to the next step of analysis shown by that display might be useful.

The third flow of analysis activities is conclusion and verification. From the beginning of data collection, qualitative analysts interpret what it means by observing patterns, explanations, causal currents, and propositions. Conclusions are also verified as results of the analyst.

\section{DISCUSSION}

The results of data analysis are obtained as follows: First group (low class); Today's modern and global economic life encourages everyone to make endeavors to survive in any way. For them to try and work are very important. They work and keep praying in accordance with their respective religions and beliefs. However, religion is not placed on very important thing in their life. It is only a part of the traditions that are passed on to it. The promises associated with the happiness of life in the world and the hereafter are not entirely trusted. This is where religious syncretism is ignored. There is no religious idealism that is strongly understood except only an obligation to live in this life. Therefore, seeking rizqi often ignores the ways that should be done according to Islam. Their habits of buying lucky draws or following practical ways to benefit material or money are made even though many are incompatible with religious teachings.

Second group (middle class): This group actually understands Islam well. Moreover, they are supported by sufficient economy, but they still feel inadequate in their economic life. This class is the largest group in Indonesia although the number is decreasing now according to government statistical data. Facing a modern and global life demanding the economics of the family is quite hard. Thus, the strong belief in religion fades increasingly. For them, religion is too ideal for the provision of life, especially living in the world. Living in the world is hard work although it sometimes violates the teachings of Islam. This group previously regarded religion ideal, but because of the economic demands and the necessities of family life, they began to ignore their religion and chose pragmatic ways to seek economic life.

Third group (high class): This group no longer have problems in economics because they are rich. They follow the teachings of religion well, but they are reluctant to improve their religious life. They already feel an ideal person because of the economic adequacy. They do not see religion as an ideal fit in life. Therefore, they run the religion in a standard and unimportant quality. However, as people who are already rich and affluent, they still want to get wealthier than what they already have. Hence, they are trapped by pragmatic ways of obtaining an unlawful economy, for example gambling, prize drawing, and so on.

\section{CONCLUSION}

From the analysis of data mentioned above, it can be concluded as follows: (1) The first group always works and prays according to religion and belief respectively. However, for them religion is not placed on something very important in life. It is only as part of the traditions that are passed on to it. The promises 
associated with the happiness of life in the world and the hereafter are not entirely trusted. This is where religious syncretism is ignored. (2) The second group shows that belief in religion that is previously strong and ideal fades more and more. For them, religion is too ideal for the provision of life especially living in the world. Living in the world takes hard work even though it sometimes violates the teachings of their own religion. This group previously regarded religion as ideal, but because of the economic demands and the

\section{REFERENCES}

[1] Bellah, Robert N., "Religious evolution" American Sociological Review 29: 358, 1964.

[2] Douglas, Mary. Purity and Danger. London: Routledge and Kegan Paul (Origin edition, 1966).

[3] Miles, Matthew B. \& A. Michael Huberman \& Johnny Saldana. Qualitative Data Analysis: A Methods Sourcebook (edition 3). Thousand Oaks, CA: SAGE. 2014.

[4] Ritzer, George. Sosiologi: Ilmu Pengetahuan Berparadigma Ganda (Sociology: a Multiple Paradigm Science). Rajawali Press. Jakarta. 2002.

[5] Sanderson, Stephen K. Sosiologi Makro: Sebuah Pendekatan Terhadap Realitas Sosial. Edisi Kedua. Jakarta, Rajawali Pers. 1993.

[6] Swanson, Guy. The Birth of the Gods. An Arbor, University of Michigan Press.

[7] Troeltsch, Ernst. The Social Teaching of Christians Churches. 2 volumes. New York: McMillan. 1931 necessities of family life, they began to ignore their religion and chose pragmatic ways to seek economic life. (3) The third group feels an ideal person because of economic sufficiency. They do not see religion as an ideal fit in life. Therefore, they practice religion in a standard and unimportant quality. However, as people who are rich and affluent, they still want to get wealthier than what they already have. Hence, they are trapped by the pragmatic ways to get an unlawful economy.

[8] Ackermann, Robert John. Religion as Critique. The University of Massachusetts Press. 1985.

[9] Glock, Charles Y., and Rodney Stark. Religion and Society in Tension. Chicago: Rand McNally. 1965.

[10] Marx, Karl. Karl Marx: Early Writings. Edited by Tom Bottomore. New York: McGraw-Hill. (Originally Written in 1843-1844). 1963.

[11] Underhill, Ralph. "Economic and political antecendents of monotheism:a cross-cultural study", American Journal of Sociology 80: 860. 1975.

[12] Wallace, Anthony F.C. Religion: An Anthropological View. New York: Random House. 1966.

[13] Weber, Max. The Protestant Ethic and the Spirit of Capilatism. New York: Charles Scribner's Sons. 1958.

[14] Yinger, J. Milton. The Scientific Study of Religion. New York: McMillan. 1970. 